\section{Impact of Zones with Special Status on the Environment (Experience of Russia and Kazakhstan)}

\author{
Irina TURGEL ${ }^{1 *}$, Larissa BOZHKO ${ }^{2}$, Ekaterina PRACHEVA ${ }^{3}, \mathrm{Abdrakhman} \mathrm{NAIZABEKOV}^{4}$ \\ ${ }^{1}$ Ural Federal University, Mira Street 19, Yekaterinburg, 620002, Russian Federation \\ ${ }^{2,4}$ Rudny Industrial Institute, 50 let Oktyabrya street 38, Rudny, 111500, Republic of Kazakhstan \\ ${ }^{3}$ Ural State University of Economics, 8 Marta street 62, Yekaterinburg, 620144, Russian Federation
}

\begin{abstract}
In the article the issues of establishing and functioning of the zones with special economic activity conditions are addressed and their impact on the environment in Russia and Kazakhstan is assessed. The relevance of the subject of the research is determined, on the one hand, by a qualitative change in the role of the environmental issues in the system of values of population of the post-soviet countries and, on the other hand, by cumulative increase of the negative impact due to the irrational environmental management. Information about the types of special status zones established in these countries is systematized. The key characteristics of these institutional entities are compared, which includes goals and specifics of their development, implemented organizational mechanisms, measures for support of business activities, offered tax incentives and preferences. The authors demonstrate that the adopted accelerated economic growth strategy within the framework of zones with special status is implemented disregarding the environmental effects of their development, which poses serious threats to self-preservation of the society and environment. Common and country-specific risks of functioning of the zones with special economic activity conditions are justified. Factors contributing to inadequate assessment of the negative impact on the environment of industries, created in SEZ were revealed. It is emphasized that the current legal and regulatory framework of these zones in Russia and Kazakhstan is aimed not at the prevention of environmental threats but at the easing of requirements for entities in the field of environmental management. Finally, conclusion is made about the greening opportunities of development of the zones with special economic activity conditions, a necessity to enhance the environmental legislation and mutual "best practices" adoption opportunities in this field in Russia and Kazakhstan. The empirical basis of the analysis is constituted by the results of the studies carried out within the framework of the research work "Enhancement of the State Regulation Policy of Accelerated Clustering of the Industrial Regions" implemented on the grounds of the grant funding of the Ministry of Education and Science of the Republic of Kazakhstan.
\end{abstract}

Keywords - Assessment of the effects; ecological economics; environment; environmental management; rational regional economics; zones with special economic activity conditions

\section{INTRODUCTION}

The Russian Federation and the Republic of Kazakhstan are united by common historical development routes, economic development background, cultural traditions, geographic boundaries. Established economic relationship, territorial division of production and labour, interdependent infrastructure also nowadays maintains bilateral links, enable convergence of

\footnotetext{
* Corresponding author.

E-mail address: i.d.turgel@urfu.ru
}

(C)2019 Irina Turgel, Larissa Bozhko, Ekaterina Pracheva, Abdrakhman Naizabekov.

This is an open access article licensed under the Creative Commons Attribution License (http://creativecommons.org/

licenses/by/4.0), in the manner agreed with Sciendo. 
the strategic future vision. One of the common strategic priorities of the two countries is economic diversification, fostering innovations and attracting investment. Thus, it is stated in the Address of the President of the Russian Federation to the Federal Assembly in 2018 that for the purpose of further restructuring of the national economy, enhancing its competitiveness it is required to engage sources of growth at a fundamentally different level. Increase of labour productivity, growth of investment and development of non-resource exports should become such sources [1]. It is particularly stressed in the Address of the President of the Republic of Kazakhstan to the Nation of Kazakhstan that the fourth industrial revolution requires deep technological, economic and social changes, introduction of new management tools [2]. In these conditions support for the regional development and cluster initiatives is particularly important for Russia and Kazakhstan. Zones with special economic activity conditions can become the key institutional element for the integration of such measures. Formation of special zones provides an opportunity to increase economic openness, guarantee economic security, foster economic growth at a regional level.

However, development of such zones is related not only to positive effects. Desire to accelerate the economic growth through development of special zones often leads to a number of negative effects related to the increased social tension, spatial differentiation, breakdown of the established local reproduction systems bridging the society, nature and economy. Among these negative effects impact on the environment should be emphasized. A dramatic increase of the anthropogenic pressures caused in the process of development of special zones, lack of adequate economic mechanisms encouraging rational environmental management, predatory behaviour towards natural resources undermine the foundations of long-term sustainable territorial development, form negative moods in the society.

In the view of the above, the authors compare the experience of special zones' development in Russia and Kazakhstan, analyse their influence on the environment, characterise the implemented legal, organizational and economic mechanisms aimed at minimizing the environmental damage. The goal of the research - characteristics of the forms of negative impact of the emerging special zones on the environment and identification of approaches of Russia and Kazakhstan to the prevention and/or minimization of the destructive environmental impact. Contents of the analysis covers the entire variety of the zones with special economic activity conditions currently being created in Russia and Kazakhstan: these are special economic zones (hereinafter - SEZ), zones of territorial development (hereinafter - ZTD), territories of rapid socio-economic development (hereinafter - TRSED), special-purpose economic zones (hereinafter - SPEZ), social entrepreneurship corporations (SEC).

\section{Methodology}

The methodological basis of the research is constituted by the works devoted to the issues of support for regional development, justification of the most efficient models of the zones with special economic activity conditions, integrated assessment of the effects of development of such zones in terms of impact on the economy, nature and society.

For the assessment of the changing role of the environmental issues within the system of values of the population of the post-soviet countries the provisions contained in the works of Pishchulov [3] and Sidorov [4] were used. Functioning specifics of the zones with special economic activity conditions in the Russian Federation is revealed in the works of Emets and Purgin [5], Vishnyakov [6], Emelyanova [7], Lisits [8], Mikhailova and Ilyina [9], Neucheva [10], Turgel and Bozhko [11], [12], Pyankova [13], Skryl [14], Krutikov, Ivanova, Akimova [15], Shvetsov [16], Myasnikova [17]. The concepts of special economic zones, zones 
of territorial development and territories of rapid socio-economic development are addressed in these works, the issues of integrated assessment of the effects of their creation are raised, environmental impact is analysed. In the works of Turgel and Bozhko [11], [12], Pyankova [13] the experience of development of similar zones in different constituent entities of the Russian Federation is considered. Another significant block are the works of Kasenova[18], Nevmatulina [19], Kovalev [20], Supatayeva [21], Tulupova, Rauandina, Lustov [22], Daribekov, Alizad [23], Khodzhaev [24], Talimova [25], Vlasova and Vechkinzova [26] devoted to the analysis of development trends and prospects of the organizational mechanisms of development of the territorial economic systems of the Republic of Kazakhstan. Responsibility of the social entrepreneurship corporations for the development of industrial zones, technology parks, management specifics of special-purpose economic zones, their development mechanisms are reviewed.

The works of Grebeneva, Aleshina and Smagulov [27], Adilbekov and Sultanov [28]; Baykenova, Bents and Sugralina [29] have a significant meaning for the assessment of the scope of negative anthropogenic impact on the environment.

Nevertheless, despite the significant research interest to the problems of development of zones with special economic activity conditions, a substantial deficit of the research devoted to the assessment of long-term impact of these zones on the environment should be mentioned. In view of the above, within the framework of the research an attempt was made to define the quality change of the role of the environmental issues in the system of social values and political discourse of the analysed countries, to characterize the scope of environmental risks associated with the implementation of the policy of accelerated economic growth of the distinguished territories of development, to assess the extent to which the issues of prevention of damage to the nature and society are taken into account in the legal and regulatory framework of the territories with special status.

\subsection{Environmental Condition as a New Element of Political Agenda}

For the economy of developing and post-socialist countries the choice between the current economic goals and long-term goals of sustainable development which, as a rule, are difficult to measure in terms of costs, is usually made in favour of the first ones. Priorities of the current economic interests prevail both among business representatives, public and municipal officials responsible for the decision-taking and ordinary salaried employees. Their motivation may significantly differ: as regards business, this is first of all the maximum profit motive, for officials - maximization of distributed rents, and as regards salaried employees - own and family's daily physical survival interests. Thus, for example, attempts to stop and shut down hazardous industries, as a rule, are accompanied by social protests of workers forced to look for a new job and a sharp decline in population of small towns [30].

However, speaking of Russia it should be mentioned that in 2017-2018 the issue of negative impact of the economic activity on human health and environment acquired a brand-new importance. Russian electronic and print mass media note that ecological protests in Russia today are more dangerous than the electoral ones [31]. It is emphasized that environmental reasons, along with protests of deceived interest-holders and investors, as well as protests due to emergencies and man-induced disasters are the most common reasons of social anger in Russia now [32]. Moreover, experts believe that the environmental situation in particular is one of the leading risks threatening to cause mass protests. The environmental issues have a strong emotional impact as health is a universal value unlike the economic development, government policy values, etc., the environmental protests unite people belonging to various social groups. Such protests do not require centralized leadership [33]. 
Nevertheless, ecology is a very wide category with a large number of protest subjects falling under it (waste collection issues, industrial emissions, quality of ambient air, quality of drinking water, radiation safety, construction of any new industrial object causing serious environmental impact and many other things). Even in case when the environmental issues are not referred to directly, many issues anyway are seen through the lens of environmental risks for the population and adding the environmental context reinforces a public campaign on any issue.

The political situation in Kazakhstan is more under control. Possibilities of organized protest movements are seriously restricted. However, also here the severity of issues related to increase of the negative environmental effects of the economic policy is growing. Experts point out that increase in extraction and processing of minerals contributes to air pollution, primarily, in the industrially developed regions, over $60 \%$ of the country's territory is vulnerable to the severest desertification, the lands of Karaganda, Kostanay, Pavlodar, East Kazakhstan, Kyzylorda Regions are contaminated by heavy metals and petroleum products, a deficit of fresh water is becoming a pressing issue because the water contaminated by toxic compounds becomes unsafe [34]. In this situation initiation of new projects, including within the framework of development of special zones may become a trigger for unrolling irreversible degradation processes of the existing environmental systems and local communities. And similar examples already exist. Thus, the attempts of implementation of new large projects in Sverdlovsk, Chelyabinsk, Voronezh Regions of Russia have faced serious resistance. In all types of special zones, both in Russia and Kazakhstan, serious environmental problems exist [33]-[36].

\subsection{Legal and Regulatory Conditions for Development of Zones with Special Economic Activity Conditions}

Currently in Russia three types of zones with special economic activity conditions can be created (special economic zones, zones of territorial development, territories of rapid socio-economic development), in Kazakhstan - two (special-purpose economic zones and social entrepreneurship corporations). Information about legal and regulatory instruments providing for a possibility of development of one or another zone and terms, for which they can be created, is given in Table 1.

\section{TABLE 1. LEGAL AND REGULATORY CONDITIONS FOR DEVELOPMENT OF ZONES WITH SPECIAL ECONOMIC ACTIVITY CONDITIONS IN RUSSIA AND KAZAKHSTAN [37]-[41]}

\begin{tabular}{|c|c|c|c|c|c|}
\hline \multirow{2}{*}{ Criterion } & \multicolumn{3}{|l|}{ Russia } & \multicolumn{2}{|l|}{ Kazakhstan } \\
\hline & SEZ & ZTD & TPSED & SPEZ & SEC \\
\hline $\begin{array}{l}\text { Legal and } \\
\text { regulatory } \\
\text { instrument setting } \\
\text { forth } \\
\text { development of a } \\
\text { new type of zone }\end{array}$ & $\begin{array}{l}\text { Federal Law No. } \\
116-\text { FZ of } \\
22.07 .2005 \text { On } \\
\text { Special } \\
\text { Economic Zones } \\
\text { in the Russian } \\
\text { Federation }\end{array}$ & $\begin{array}{l}\text { Federal Law No. } \\
\text { 392-FZ of } \\
\text { 03.12.2011 On the } \\
\text { Zones of Territorial } \\
\text { Development in the } \\
\text { Russian Federation } \\
\text { and On Amending } \\
\text { Individual Legal } \\
\text { Acts of the Russian } \\
\text { Federation }\end{array}$ & $\begin{array}{l}\text { Federal Law } \\
\text { No. } 473 \text {-FZ of } \\
29.12 .2014 \text { On } \\
\text { the Territories } \\
\text { of Rapid Social } \\
\text { and Economic } \\
\text { Development of } \\
\text { the Russian } \\
\text { Federation }\end{array}$ & $\begin{array}{l}\text { Law of the } \\
\text { Republic of } \\
\text { Kazakhstan No. } \\
469 \text {-IV of } 21 \text { July } \\
2011 \text { On Special } \\
\text { Purpose Economic } \\
\text { Zones in the } \\
\text { Republic of } \\
\text { Kazakhstan }\end{array}$ & $\begin{array}{l}\text { Resolution of the } \\
\text { Government of the } \\
\text { Republic of } \\
\text { Kazakhstan No. } 483 \text { of } \\
31 \text { May } 2006 \text { on the } \\
\text { Concept of } \\
\text { Development of } \\
\text { Regional Social } \\
\text { Entrepreneurship } \\
\text { Corporations }\end{array}$ \\
\hline $\begin{array}{l}\text { Term of zone } \\
\text { development }\end{array}$ & 49 years & 12 years & 70 years & 25 years & 10 years \\
\hline
\end{tabular}




\begin{tabular}{|c|c|c|c|c|c|}
\hline $\begin{array}{l}\text { Legal and } \\
\text { regulatory } \\
\text { instrument } \\
\text { establishing } \\
\text { decision on } \\
\text { development of } \\
\text { specific zones }\end{array}$ & $\begin{array}{l}\text { Resolution of the } \\
\text { Government of } \\
\text { the Russian } \\
\text { Federation }\end{array}$ & $\begin{array}{l}\text { Resolution of the } \\
\text { Government of the } \\
\text { Russian Federation }\end{array}$ & $\begin{array}{l}\text { Resolution of } \\
\text { the Government } \\
\text { of the Russian } \\
\text { Federation }\end{array}$ & $\begin{array}{l}\text { Presidential } \\
\text { Decree, } \\
\text { Resolution of the } \\
\text { Government of the } \\
\text { Republic of } \\
\text { Kazakhstan }\end{array}$ & $\begin{array}{l}\text { Resolution of the } \\
\text { Government of the } \\
\text { Republic of } \\
\text { Kazakhstan }\end{array}$ \\
\hline
\end{tabular}

On a whole, a longer period of maximum possible functioning of the zones with special economic activity conditions is characteristic of the Russian Federation (SEZ - up to 49 years, TRSED - up to 70 years). The legal and regulatory basis of development and functioning of such form of special zones as SEC has not yet been fully developed in Kazakhstan.

Such types of zones are characterized also by different spatial features of localization. For example, SEZ has a clearly restricted area, they are created on the land, which is property of the state or municipality, including the one given into possession or use to natural or legal persons and on the land, which is property of citizens or legal persons. Special economic zones may not occupy territory of the entire municipality (several municipalities). TRSED and ZTD may be created on a territory of a municipality or on territories of several municipalities within one constituent entity of the Russian Federation. All these three zones may not be located on the territory of the same municipality of the Russian Federation. SPEZ, which are under development in Kazakhstan, from the point of view of preferred approach to spatial localization are the closest to the Russian special economic zones. SPEZ is a geographically localized land with precise boundaries. Such a unique institution as a social entrepreneurship corporation stands out to a certain extent. At first glance it feels like that we try to compare basically different entities. However, owing to a unique nature of the model of organization of a social entrepreneurship corporation such comparison is feasible. A social entrepreneurship corporation is a national company of the Republic of Kazakhstan which realizes the idea of a Public Private Partnership through cooperation of the state and business. They are established as non-commercial corporations and are aimed at dealing with challenges of reinvesting the profits made into social projects of the regions, in whose interests they have been created. Each SEC has its own "zone of responsibility", which includes several Kazakhstan regions.

All zones are basically united by a common goal - acceleration of the socio-economic development of the region. SEZ and SPEZ are oriented to development of modern, highly efficient and competitive production. On the opposite, the zones of territorial development and TRSED are being created within the framework of the most economically disadvantaged constituent entities of the Russian Federation or such having some serious local problems, they are to a larger degree targeted at solving the issues of the cross-regional equalization. At present ZTD can be established in 20 constituent subjects of the Russian Federation.

It should be noted that the largest scope of various preferences for residents in Russia is ensured by TRSED, in Kazakhstan - by SPEZ. The smallest amount of preferences is available to ZTD. In particular, ZTD do not have the advantage of free customs zone. Residents of ZTD may expect tax incentives within the framework of tax authorities of regional and local budgets.

And, finally, from the point of view of the scope of activities, free economic zones in Kazakhstan and special economic zones in Russia play the key role for the economic development today. Data on the number of zones of different types are provided in Table 2. 
TABle 2. PREVAlENCE OF ZONES With SPECIAl ECONOMIC ACTIVITy CONDITIONS

\begin{tabular}{|c|c|c|c|c|}
\hline \multicolumn{3}{|l|}{ Russia } & \multicolumn{2}{|l|}{ Kazakhstan } \\
\hline SEZ & ZTD & TPSED & SPEZ & SEC \\
\hline $\begin{array}{l}28 \text {, out of them }-10 \text { industrial and production zones, } 6 \\
\text { technical innovation zones, } 7 \text { tourist and recreational } \\
\text { zones, } 1 \text { port zone, general type }-2 \text {, transferred to the } \\
\text { regional level }-2 \text {. } 10 \text { SEZ have been closed }\end{array}$ & $\begin{array}{l}\text { Can be established } \\
\text { in } 20 \text { constituent } \\
\text { subjects of the } \\
\text { Russian Federation }\end{array}$ & 100 & $\begin{array}{l}10 \text {, as well as } 23 \\
\text { industrial zones of } \\
\text { production } \\
\text { infrastructure }\end{array}$ & 16 \\
\hline
\end{tabular}

Although technically the biggest number of zones with special economic activity conditions have been created in the form of TRSED, from the point of view of contribution to the country's economic development they are significantly outpaced by special economic zones. Thus, during 12 years of operation over 650 residents have registered in SEZ, of which more than 100 companies with foreign capital from 35 countries of the world. Over the years the total volume of declared investment exceeded 850 billion roubles, made investment - more than 260 billion roubles, more than 25 thousand jobs have been created, more than 67 billion roubles of tax and customs payments have been made [42]. The ZTD creation potential has not been realized.

\subsection{Negative Environmental Effects of the Functioning of Zones with Special Economic Activity Conditions}

According to the data above, the zones with special economic activity conditions have already become an integral part of the economy of Russia and Kazakhstan. On a whole, development of the legal and regulatory framework has been completed. Outsiders have become apparent (namely, ZTD who have not become real tools of the regional policy). The economic efficiency issues of special zones, issues of building an optimal set of tax incentives are actively discussed. However, attempts of integrated assessment of effects of their development, including assessment of impact on the environment are difficult to realize due to the unavailability of an appropriate statistical base. Due to the limited availability of the official data the authors conducted a content analysis of electronic and print mass media of several regions of Russia and Kazakhstan having functioning zones with special economic activity conditions. The results of this analysis reflecting the opinion of local communities about the most significant environmental issues of these special zones are provided in Table 3.

TABLE 3. ENVIRONMENTAL ISSUES OF SOME SPECIAL ZONES OF RUSSIA AND KAZAKHSTAN [43]-[46]

$\begin{array}{ll}\begin{array}{l}\text { Special } \\ \text { economic }\end{array} & \text { SEZ Titanium Valley (Sverdlovsk Region): 1) ambient air pollution, 2) pollution of surface waters by } \\ \text { zones } & \text { facility wash-downs and heavy metals, 3) pollution of land surface due to waste disposal, 4) increase } \\ \text { (Russia) } & \text { in the consumption of water for productive purposes, 5) chemical contamination of soil, reoccurrence } \\ \text { of atmospheric air pollution (dusting at dumps, evaporation at sludge depositories), 6) radioactive and } \\ \text { thermal pollution (risks related to construction of a nuclear power station in the district of Kushva } \\ \text { town). } \\ \text { SEZ “Alabuga": 1) ambient air pollution, 2) deterioration of the quality of drinking water, } \\ \text { 3) generation of toxic waste and its management problem, 4) small amount of greenery and poor site } \\ \text { improvements. } \\ \text { Tourist and recreational zones of Kuban: 1) ambient air pollution, 2) household and municipal waste } \\ \text { pollution, 3) degradation of landscape, erosion of slopes and soil loss, 4) deficit of drinking water } \\ \text { supply, 5) sea-water pollution (microbial, ports, ship repair yards and oil refineries, oil products from } \\ \text { ships), 6) pollution of environment by pesticides (accumulation of hazardous compounds in soil, sea } \\ \text { water and ground), 7) development in the first zone of sanitary protection. }\end{array}$




\begin{tabular}{|c|c|}
\hline \multirow{2}{*}{$\begin{array}{l}\text { Territories of } \\
\text { rapid socio- } \\
\text { economic } \\
\text { development } \\
\text { (Russia) }\end{array}$} & $\begin{array}{l}\text { TRSED "Krasnoturyinsk": 1) ambient air pollution by harmful emissions (fluorine compounds, } \\
\text { sulphur dioxide and nitrogen dioxide), 2) flotation tailings of the copper mine of Turyinsk, 3) dredge } \\
\text { landscape disfigurement after alluvial gold and platinum mining on the riverbeds of Turya, Sosva } \\
\text { rivers and their tributaries, 4) pollution of river water, 5) illegal dumps, 6) soil pollution. }\end{array}$ \\
\hline & $\begin{array}{l}\text { TPSED "GornyVozdukh": 1) increased risk of mudslides, 2) mass felling of trees, 3) lack of } \\
\text { infrastructure for waste recycling and disposal, 4) uncontrolled catching of salmon fishes, 5) } \\
\text { pollution of sea and river water, 6) low efficiency of treatment facilities, 7) lack of beach suitable for } \\
\text { bathing. }\end{array}$ \\
\hline \multirow[t]{2}{*}{$\begin{array}{l}\text { Special- } \\
\text { purpose } \\
\text { economic } \\
\text { zones } \\
\text { (Kazakhstan) }\end{array}$} & $\begin{array}{l}\text { SPEZ "Saryarka" in Karaganda Region: 1)ambient air pollution due to emissions of industrial } \\
\text { enterprises (production processes and burning provide a whole range of hazardous substances), } \\
\text { 2) pollutants accumulate in the surface air and their concentration persists for a long time as a result } \\
\text { of low city airing capacity, 3) exhaust gas is one of the principal sources of the ambient air pollution } \\
\text { by nitrogen dioxide, carbon monoxide, organic matters, etc., 4) insufficient greenery, 5) pollution of } \\
\text { reservoirs, 6) ammunition depots (as a result of burning and explosions chlorinated POPs could form } \\
\text { as solid propellant contains perchlorates as an oxidizer and synthetic rubber as a binding } \\
\text { component). }\end{array}$ \\
\hline & $\begin{array}{l}\text { SPEZ "Chemical Park Taraz" in the city of Taraz: 1) a large number of improvised dumps (toxic } \\
\text { waste sites and lack of companies specializing in its treatment), 2) ambient air pollution due to } \\
\text { emissions of industrial enterprises, 3) low efficiency of treatment facilities, 4) absence of greenery, } \\
\text { 5) increase of the salt concentration in drinking water in populated localities situated along the river, } \\
\text { 6) radioactive pollution. }\end{array}$ \\
\hline
\end{tabular}

Thus, both the environmental risks common for all regions of Russia and Kazakhstan (illegal dumps, unavailability of waste treatment system) and specific risks resulting from the character of economic activity are observed in the special zones.

\subsection{Fair Evaluation of Negative Environmental Effects of Zones with Special Economic Activity Conditions}

There is a question arisen about the reasons for such a negative reaction of the society to SEZ development. At the first glance, one of the main tasks in creating these zones is the construction of new enterprises using modern technologies that minimize negative consequences for the environment. For example, conditions for creation of most zones in Russia imply restrictions on the location of industries with a high level of danger to the environment. To answer this question, the analysis of the situation that arose in the process of SEZ creating in Sverdlovsk Region (RF) was made. The object of the analysis was the two zones: SEZ Titanium Valley (located in the city of VerkhnyayaSalda) and TRSED "Krasnoturyinsk" (located in the city of Krasnoturyinsk). It was planned to locate manganese alloys production - a new resident is LLC Inferkom-Ural. These industries should have been a part of the overall process cycle. The TRSED "Krasnoturyinsk" should be carried out enrichment and production of manganese metal. It was planned to organize a new, extra-furnace method of smelting manganese. Ferroalloys, manganese dioxide, manganese and electrolytic manganese dioxide (EMD) were to be the final product. Then, manganese alloys should be released on the site of "Titanium Valley". However, a sharply negative reaction from local communities forced the construction to stop and conduct additional impact assessments. Analysing the current situation, the authors highlight the following points that are important for shaping the policy for SEZ development.

First, carrying out of comprehensive and realistic assessment of environmental state in cities, which are the territory of localization of special zones [47]. In this case, it was planned to place metallurgical production in cities that are currently characterized by a negative environmental situation. Krasnoturinsk and Verkhnyaya Salda are two small industrial mono-cities. A brief description of the industrial complex of these cities is given in Table 4. 
TABLE 4. CHARACTERISTICS OF THE INDUSTRIAL COMPLEX OF
KRASNOTURINSK AND VERKHNYAYA SALDA, 2017 [48]

\begin{tabular}{|c|c|c|c|c|c|}
\hline City & $\begin{array}{l}\text { Population, } \\
\text { people }\end{array}$ & $\begin{array}{l}\text { Economic } \\
\text { specialization }\end{array}$ & $\begin{array}{l}\text { City forming } \\
\text { enterprise }\end{array}$ & $\begin{array}{l}\text { Assessment of } \\
\text { the current } \\
\text { environmental } \\
\text { situation }\end{array}$ & $\begin{array}{l}\text { Zone with special } \\
\text { conditions of } \\
\text { economic activity }\end{array}$ \\
\hline Krasnoturinsk & 62602 & $\begin{array}{l}\text { Non-ferrous } \\
\text { metallurgy: bauxite, } \\
\text { alumina; mining of } \\
\text { non-ferrous metals }\end{array}$ & $\begin{array}{l}\text { Bogoslovskiy } \\
\text { Aluminum Plant, } \\
\text { Bogoslovskiy } \\
\text { Mine } \\
\text { Administration, } \\
\text { Turinsky mine, } \\
\text { ZAO Gold of the } \\
\text { Northern Urals }\end{array}$ & $\begin{array}{l}\text { Unfavourable in } \\
\text { terms of air } \\
\text { pollution, water } \\
\text { quality, } \\
\text { disposed waste } \\
\text { and soil } \\
\text { pollution }\end{array}$ & $\begin{array}{l}\text { TRSED } \\
\text { "Krasnoturyinsk" } \\
\text { enrichment and } \\
\text { production of } \\
\text { manganese metal }\end{array}$ \\
\hline $\begin{array}{l}\text { Verkhnyaya } \\
\text { Salda }\end{array}$ & 45737 & $\begin{array}{l}\text { Nonferrous } \\
\text { metallurgy, } \\
\text { mechanical } \\
\text { engineering (full cycle } \\
\text { of production of } \\
\text { semi-finished products } \\
\text { from titanium alloys) } \\
\text { by machining }\end{array}$ & $\begin{array}{l}\text { PJSC } \\
\text { "VSMPO-AVISMA } \\
\text { Corporation" }\end{array}$ & $\begin{array}{l}\text { Unfavourable in } \\
\text { terms of water } \\
\text { quality, waste } \\
\text { placed }\end{array}$ & $\begin{array}{l}\text { SEZ Titanium } \\
\text { Valley Manganese } \\
\text { Alloys Release }\end{array}$ \\
\hline
\end{tabular}

The most difficult situation is in Krasnoturinsk, where long-term negative trends in environmental pollution (long-term high levels of air pollution that do not meet hygienic standards, water quality in drinking water sources, increase in the area of disturbed land and the mass of waste placed, soil pollution) and public health condition characterize the city as a territory with a poor environmental situation. In Verkhnyaya Salda there are serious problems associated with industrial waste treatment, removal and disposal of industrial waste VSMPO "Avisma".

Secondly, a thorough study of the history of industrial territory development. Thus, in the course of experts surveying, it was revealed that in the Soviet period, a plant for the production of manganese alloys existed in Verkhnyaya Salda at a town-forming enterprise for a long time. At present, there is no accurate information about consequences of this production, used conservation regimes, waste disposal sites, etc. This creates additional hardly predictable risks of cumulative amplification of negative environmental consequences for placing a new production.

Thirdly, strict control in the process of establishing the hazard class of the production facilities. Thus, in accordance with the Law of the Russian Federation, production of ferroalloys belongs to the first (most dangerous) class. But in accordance with the conditions for SEZ creation, production above IV-V hazard classes cannot be located here [49]. At the moment, special attention should be paid since representatives of regional authorities are highly motivated in demonstrating positive dynamics in development of special zones in front of their upper management and are often illegible in their choice of residents.

Fourth, the study of real spatial zoning of the territory of production localization So, in Krasnoturinsk and Verkhnyaya Salda there were significantly violated the requirements for the distance of accommodation of residential areas in relation to industrial facilities. Another point is the citizens' distrust of official decisions to reduce the radius of the "exclusion zones" around industrial facilities due to reduction of their negative environmental impact [50]. The cumulative effect of these two factors has led to inability to assess the real boundaries of the exclusion zone for new industries. 
The analysis showed that the reasons for incorrect assessment of the negative environmental consequences of locating production in special zones identified in Russia are also valid for the Republic of Kazakhstan (Table 5).

TABLE 5. DEGREE of ViOLATION DiSTRIBUTION IN THE ASSESSMENT OF ECOLOGICAL CONSEQUENCES OF CREATING ZONES WITH SPECIAL CONDITIONS OF ECONOMIC ACTIVITY IN THE REPUBLIC OF KAZAKHSTAN

\begin{tabular}{llll}
\hline & $\begin{array}{l}\text { Lack of integrated assessment } \\
\text { of the cumulative effect of } \\
\text { existing and planned negative } \\
\text { environmental impacts }\end{array}$ & $\begin{array}{l}\text { Unreliable assessment of } \\
\text { the hazard class of a new } \\
\text { production }\end{array}$ & $\begin{array}{l}\text { Inaccurate assessment of } \\
\text { existing spatial zoning of the } \\
\text { territory (placement of } \\
\text { residential and industrial areas }\end{array}$ \\
\hline $\begin{array}{l}\text { The proportion of } \\
\begin{array}{l}\text { zones where } \\
\text { violations were found }\end{array}\end{array}$ & 85 & 40 & 70 \\
\hline
\end{tabular}

\subsection{Measures for Reduction of Environmental Risks in Developing Zones with Special Economic Activity Conditions}

Despite the existence of serious environmental problems, the measures for reducing the environmental risks are insufficient and fragmentary [51].

Thus, analysis of the legal and regulatory framework providing for development of SEZ in the Russian Federation allowed to identify the following provisions associated with the regulation of the environmental impact:

1. Reducing the time of the state environmental expertise of infrastructure objects to 45 days (basic option of duration of the environmental expertise - up to 2 months);

2. Increasing capacity for the use of land. Tourist and recreational SEZ can be created on the land falling under the category of land of special protection territories and objects or land of the forest fund, agricultural land;

3. Increasing capacity for the use of a number of natural resources. A resident of a tourist and recreational SEZ is entitled to carry out activities for development of mineral water deposits and other natural healing resources, as well as for production bottling of mineral water. A resident of a port SEZ is entitled to carry out processing of aquatic biological resources.

TRSED capacities for mitigating the existing common environmental management regime are equal.

1. The right of the Government of the Russian Federation is established to lay down specific aspects for the regulation of relations in the field of fish farming, as well as fishing and preservation of aquatic biological resources. There is no such right in other zones;

2. In case of deployment of TRSED infrastructure facilities, deployment on the forest land is permitted. For the purpose of deployment of infrastructure facilities in forests selective and clear cutting is permitted.

The following regulatory standards are introduced in Kazakhstan as well:

1. Within public procurement preference is given to suppliers whose commodities have received "voluntary certification for commodities from secondary raw materials obtained from waste on the territory of the Republic of Kazakhstan";

2. Permitting procedures in the field of environment protection have been simplified for small enterprises located on the territory of SPEZ and having insignificant impact (termless environmental permit, no need to conduct public hearings, etc.);

3. Giving back to the state of disturbed land by the large subsoil users in SEC is 
performed only based on orders and claims on the part of environmental inspection.

Thus, the legislation of Russia and Kazakhstan basically does not prevent but directly encourages consumer attitude to the environment, does not create necessary leverage over dishonest investors.

\section{Conclusions}

- The modern period of socio-economic and political development of Russia and Kazakhstan is characterized by the increase of attention to the environment protection issues, persistent efforts to reconsider the traditional system of priorities. Within the framework of this traditional system practically all social groups opt for the economic growth in a short-term aspect, disregarding long-term interests of sustainable development. The observed shift in paradigm shows that the environment preservation issues become more significant than the issues of retaining production plants and jobs, enable rapid uniting of different social groups and become leaders of the protesting agenda;

- Proclaimed goals of development of special zones initially do not provide for the goals associated with ensuring sustainable development, environment protection. Russia and Kazakhstan share the same aspirations - to give an impetus to development of regions, to attract new investment. Similarly, favourable living conditions and employment of population are proclaimed as goals of development of TRSED and SPEZ;

- In all types of actually functioning special zones serious negative environmental effects have been identified. In general, both the effects common for all regions of Russia and Kazakhstan (illegal dumps, unavailability of waste treatment system) and specific effects resulting from the character of economic activity can be distinguished. This being said, a significant deficit of official information available to researchers and people concerning possible environmental risks and ways to overcome them exists;

- Assessment of the negative environmental consequences of creating zones with special conditions for economic activity should be comprehensive, unbiased. At the same time, it is necessary to consider existing economic specialization of the territory of localization of a special zone, possibility of cumulative strengthening of negative environmental effects, history of economic development of the territory, the actual spatial zoning of the city, reflecting the actual, rather than the formal placement of residential and industrial zones;

- Legal and regulatory regimes of the zones with special economic activity conditions do not foster minimization of negative impact on the environment. On the contrary, in many cases they reduce effective restrictions, increase opportunities of economic entities both from the standpoint of pursued types of economic activity and the scope of natural resources being engaged;

- Prospects for further enhancement of activity of special zones in the economy of the Russian Federation and Republic of Kazakhstan very much depend on increasing the legislation efficiency in the field of regulation of activity of these institutions, as well as on efficiency of the control methods and its implementation monitoring. Turbulence of the socio-economic and political situation with a high probability may lead to a new range of problems to be solved by Russia and Kazakhstan. And in this relation, it is important to come to a new stage with comprehension of the existing problems and a wise plan for their solution. 


\section{REFERENCES}

[1] Address of the President of the Russian Federation to the Federal Assembly [Online]. [Accessed 11.08.2018]. Available: http://www.kremlin.ru/events/president/news/56957

[2] Address of the President of the Republic of Kazakhstan to the Nation of Kazakhstan [Online]. [Accessed 11.08.2018]. Available: http://www.akorda.kz/ru/addresses/addresses_of_president/poslanie-prezidenta-respubliki-kazahstan-nnazarbaeva-narodu-kazahstana-10-yanvarya-2018-g

[3] Pishchulov V. M. Global ecology - Economics and Finance: monograph. Yekaterinburg: Ural State Forest Engineering University, 2016.

[4] Sidorov V. A. Globalnaja ekologija i problemi ekonomicheskogo rosta v Rossii. Finansii Kredit 2004:23(161):48-54. (in Russian)

[5] Emec M. I., Purgin A. S. Sravnitelnij analiz instrumentov regionalnoj politiki RF: osobye ehkonomicheskie zony, zony territorialnogo razvitiya $I$ territorii operezhayuschego socialno-ekonomicheskogo razvitiya. Ekonomika, gosudarstvo, obshchestvo 2015:4:28. (in Russian)

[6] Vishnyakov V. G. Special Economic Zones: legal and development issues. Journal of Russian Law 2015:1:23. (in Russian)

[7] Jemeljanova K. The history of the establishment of the institute of special economic zones in Russia. Scientific community of students: Interdisciplinary Research: XI International Scientific and Practical Conference. 2016:8(11). [Online]. [Accessed 15.07.2018]. Available: https://sibac.info/archive/meghdis/8(11).pdf (in Russian)

[8] Lisitsa V. N. Ponatie osoboj ekonomicheskoj zoni: otgranichenie ot smezhnih territorij. Vestnik of Federal Service for State Registration 2010:6:26-38. (in Russian)

[9] Mihailova E. S., Ilina E. A. Osobaja ekonomicheskaja zona kak slozhnoorganizovannaja kompleksnaja ekonomicheskaja sistema. Socialno-ekonomicheskie problemi razvitija ekonomiki APK v Rossii i za rubezhom. AllRussian Scientific and Practical Conference of Students, Graduate Students and Young Scientists. Irkutsk State Agrarian University named after A.A. Ezhevsky. 2017:108-116. (in Russian)

[10] Neucheva M. Yu. Special economic zones and the solution of socio-economic problems of the territories. Problems of Modern Economics 2011:2(38):248-251. (in Russian)

[11] Turgel I., Bozhko L., Leskova L. State Support of Monotowns in Russia and Kazakhstan: Experience and Problems. Energy Procedia 2016:95:559-563.doi:10.1016/j.egypro.2016.09.085

[12] Turgel I., Panzabekova A., Satpayeva Z. Comparative analysis of approaches to designing of regulatory impact assessment institute in Russia, Kazakhstan, and Kyrgyzstan. Vestnik Nacionalnoj Akademii Nauk Respubliki Kazahstan 2018:4:153-160.

[13] Naizabekov A., Bozhko L. Future development of cluster initiatives in the Republic of Kazakhstan. Energy Procedia 2018:147:654-659. doi:10.1016/j.egypro.2018.07.085

[14] Skryl T. V. The territory of advanced development mechanism as an element of sustainable economic growth. Economics of Education 2016:2(93):135-147.

[15] Khabdullin A., Khabdullina Z., Khabdullin A., Khabdullina G., Lauka D., Blumberga D. Analysis of Industrial Electricity Consumption Flexibility. Assessment of Saving Potential in Latvia and Kazakhstan. Energy Procedia 2016:113:450-453. doi:10.1016/j.egypro.2017.04.037

[16] Turgel I., Bozhko L., Leskova L. State support of monotowns in Russia and Kazakhstan: Experience and Problems. Energy Procedia 2016:95:559-563. doi:10.1016/j.egypro.2016.09.085

[17] Myasnikova O. Advanced development territory as an instrument of economic development. Bulletin of Science and Practice 2018:4(7):323-328. (in Russian)

[18] Kasenova R.K. Opyt sozdaniya specialnih ekonomicheskih zon v respublike Kazahstan. Ekonomika i upravlenie: analiz tendencij i perspektiv razvitiya 2013:5:44-47. (in Russian)

[19] Khabdullin A., Khabdullina Z., Khabdullina G., Lauka D., Blumberga D. Demand response analysis methodology in district heating system. Energy Procedia 2017:128:539-543. doi:10.1016/j.egypro.2017.09.004

[20] Kovalev I. L. Analiz investicionnogo klimata v Belarusi, Kazahstane i Rossii v ramkah EEHP. Problemi razvitiya territorii 2014:6(74):150-166. (in Russian)

[21] Bozhko L. Assessment of Approaches to Industrialization Issues in the Republic of Kazakhstan and the People's Republic of China. Energy Procedia 2017:113:482-487. doi:10.1016/j.egypro.2017.04.046

[22] Tulupova S. A., Raundina G. K., Lustov N. S. Sozdanie specialnoj ekonomicheskoj zoni "Khorgos-vostochnie vorota" kak osnovnoj faktor realizacii tranzitnogo potenciala respubliki Kazahstan. Problemi ekonomiki 2015:2(66):51-52. (in Russian)

[23] Khabdullin A., Khabdullin A., Khabdullina Z., et al. Mathematical model of synchronous motors for static characteristics power loss. Energy Procedia 2015:95:487-490. doi:10.1016/j.egypro.2016.09.073

[24] Khodzhaev D. Socialno-predprinimatelskie korporacii respubliki Kazahstan kak pravovoy mehanizm zaschiti interesov grazhdanskogo obschestva. Itogi pervogo desyatiletiya. Molodoy Uchyoniy 2016:23(127):66-70. (in Russian) 
[25] Bozhko L. Development scenarios for the interregional economic interaction in the context of economy clustering in the Republic of Kazakhstan. Energy Procedia 2018:147:397-401. doi:10.1016/j.egypro.2018.07.109

[26] Francmanis E., Khabdullin A., Khabdullin A., et al. Comparative environmental analysis of microbial electrochemical systems. Energy Procedia 2015:95:564-568. doi:10.1016/j.egypro.2016.09.086

[27] Grebeneva O. V., Aleshina N. Yu., Smagulov N. K. Modern assessment of air pollution in Karaganda. Medicine and Ecology 2018:3(88):26-32.

[28] Adilbekov E. K., Sultanov T. T. Review of renewable energy sources in the Republic of Kazakhstan. Bulletin of the L. N. Gumilyov Eurasioan National University. Series: Technical Science and Technology 2018:1(122):8-14. (in Russian)

[29] Baikenova G. G., Benz T. V., Sugralina L. M. Analysis of the quality of water resources of the Republic of Kazakhstan. Bulletin of the Karaganda University. Chemistry 2017:4(88):104-108.

[30] Life. Baikal Pulp and Paper Mill, Which Polluted the Lake for Half a Century, Shuts Down [Online]. Available:https://life.ru/t/\%D0\%BD\%D0\%BE\%D0\%B2\%D0\%BE\%D1\%81\%D1\%82\%D0\%B8/124619

[31] Experts: Environmental Protests are More Dangerous than Electoral Ones in Russia Today [Online]. Available: https://ria.ru/20180413/1518522121.html

[32] The Centre for Economic and Political Reforms. Protest Activity Increase in Russia: Results of the Russian National Monitoring 2017-2018 [Online]. Available: http://cepr.su/2018/11/08/protests-2017-2018/

[33] Sources and risks of protest activity in 2018. Minchenko Consulting Report [Online]. Available: http://www.minchenko.ru/analitika/analitika_79.html

[34] Nur.KZ. Environmental Issues of Kazakhstan and Their Solution [Online]. Available: https://www.nur.kz/1666860-ekologicheskie-problemy-kazakhstana.html

[35] New Environmental Code Requires Intersectoral Unity [Online]. Available: http://atameken.kz/ru/news/28715-novyj-ekologicheskij-kodeks-trebuet-mezhotraslevogo-edinstva

[36] Kulibaev T. Environmental Payments Should Be Targeted. It Will Ease Gradual Introduction of "Green" Technologies for Businesses in Kazakhstan [Online]. Available: https://kapital.kz/economic/69413/timur-kulibaev-ekologicheskie-platezhi-dolzhny-stat-celenapravlennymi.html

[37] Federal Law No. 116-FZ of 22.07.2005 On Special Economic Zones in the Russian Federation.

[38] Federal Law No. 392-FZ of 03.12.2011 On the Zones of Territorial Development in the Russian Federation and On Amending Individual Legal Acts of the Russian Federation.

[39] Federal Law No. 473-FZ of 29.12.2014 On the Territories of Rapid Socio-Economic Development of the Russian Federation.

[40] Law of the Republic of Kazakhstan No. 469-IV of 21 July 2011 On Special-Purpose Economic Zones in the Republic of Kazakhstan.

[41] Resolution of the Government of the Republic of Kazakhstan No.483 of 31 May 2006 on the Concept of Development of Regional Social Entrepreneurship Corporations.

[42] Special economic zones. Official site of the Ministry of Economic Development of the Russian Federation [Online]. [Accessed 11.08.2018]. Available: http://economy.gov.ru/minec/activity/sections/sez

[43] Concerns of the People Over Environmental Situation in Relation to Development of a Special Economic Zone of the Industrial and Production Type "Alabuga" [Online]. [Accessed 23.03.2019]. Available: https://moluch.ru/archive/90/18739

[44] Krasnoturyinsk - Environmental Situation [Online]. [Accessed 23.03.2019]. Available: https://mindfactor.ru/questions/2092432

[45] "Help, we are being driven out of a place!" - a little bit about Sakhalin ecology [Online]. [Accessed 23.03.2019]. Available: http://www.kprf-sakhalin.ru/2018/08/06/karaul-nas-vyzhivayut-nemnogo-ob-ekologii-sahalina

[46] Environmental Problems of the Zhambul Region [Online]. [Accessed 23.03.2019]. Available: http://kazorta.org/ekologicheskie-problemy-zhambylskoj-oblasti/

[47] Albatayneh A., Alterman D., Page A., Moghtaderi B. The Significance of Building Design for the Climate. Environmental and Climate Technologies 2018:22:165-178. doi:10.2478/rtuect-2018-0011

[48] Database of municipal indicators [Online]. [Accessed 03/23/2019] Available: http://www.gks.ru/free_doc/new_site/bd_munst/munst.htm

[49] Federal law N 116-FZ of 21.07.1997. On industrial safety of hazardous production facilities.

[50] Bajcinovci B. Environment Quality: Impact from Traffic, Power Plant and Land Morphology, a Case Study of Prishtina. Environmental and Climate Technologies 2017:19(1):65-74. doi:10.1515/rtuect-2017-0006

[51] Bajcinovci B. Environmental and Climate Dilemma: Coal for Heating or Clean Air for Breathing: A Case of Prishtina. Environmental and Climate Technologies 2019:23(1):41-51. doi:10.2478/rtuect-2019-0003 